\title{
THE PLEXUS CHORIOIDEUS IN THE ADULT GOAT: A SCANNING
} ELECTRON MICROSCOPE STUDY

\author{
V. RAJTOVÁ \\ Department of Anatomy and Histology, University of Veterinary Medicine, \\ Košice, Slovak Republic \\ Received May 15, 2000 \\ Accepted July 27, 2000
}

Abstract

Rajtová V .: The Plexus Chorioideus in the Adult Goat: A Scanning Electron Microscope Study. Acta Vet. Brno 2000, 69: 167-171.

The surface of plexus chorioideus of the fourth, third and lateral ventricle and in the region of the foramen interventriculare of adult goats of both sexes was studied using scanning electron microscopy. It was found that the convex apical membranes on the whole surface of the plexus chorioideus are covered with microvilli or microvillus-like structures. The presence of cilia was not recorded. Abundant spherical protrusions occurred in the region of lateral cerebral ventricle, and were almost absent in the region of the foramen interventriculare. The epiplexal cells occurred in the fourth and lateral ventricle only sporadically; they could be seen in higher number in the third ventricle and in the region the foramen interventriculare. Some epiplexal cells had a large number of filiform processes; most of these macrophage-like cells had only 3-5 pseudopodia with "ruffled" membranes. No differences which would be connected with sex or season were found in the structure of the plexus chorioideus.

Central nervous system, plexus chorioideus, cerebral ventricles, microvilli, secretory protrusions, epiplexal cells, adult goat

The plexus chorioideus $(\mathrm{PCH})$ is situated in the cerebral ventricles and produces the greater part of the cerebrospinal fluid. It is a part of pial blood vessels invaginated into the ventricular space, villi formly arranged and covered with one layer of predominantly cuboid epithelial cells. Their apical membranes have a characteristic structure, which is very similar to the apical membranes of ependymal cells of the cerebral ventricular system (presence of microvilli, spherical protrusions or macrophage-like cells).

The PCH surface was studied by the scanning electron microscope in various species of mammals in their prenatal or postnatal life (in the rat-Chamberlain 1973; Hos oy a and Fujita 1973; Peters 1974; Peters and Swan 1979, in the dog-Allen 1975; Persky 1980, in the cat - Clementi and Marini 1972, in the macaque - Coates 1977; Ling 1983, in humans - Scott et al. 1972, 1974; O’Rahilly and Müller 1990; Otani and Tanaka 1988). Some authors focused on the description of the structure of epiplexal (Kolmer's) cells (EPC) or their classification and origin (Carpenter et al. 1970; Kitamura 1973; Sturrock 1978; Maxwell and McGadey 1988). There is no record on the plexus chorioideus in the adult goat in the literature.

The aim of the work was to study the plexus chorioideus surface in adult goats by scanning electron microscope.

\section{Materials and Methods}

Twelve adult goats of both sexes ( 9 females and 3 males) were used. They were killed between spring and autumn. Immediately after exsanguination, the heads of animals were perfused through a. carotis communis with $0.2 \mathrm{~mol} / \mathrm{l}$ phosphate buffer solution and prefixed with Karnovsky solution. The specimens of the plexus chorioideus from the fourth, third and lateral ventricles and from the region of the foramen interventriculare were postfixed in

Address for correspondence:

Prof. MVDr. Viera Rajtová, DrSc.

Department of Anatomy and Histology

Komenského 73,041 81 Košice, Slovak Republic
Phone: +421956229924

Fax: +421956323666

http://www.vfu.cz/acta-vet/actavet.htm 
$3 \%$ glutaraldehyde in cacodylate buffer (temperature of all solutions was $4{ }^{\circ} \mathrm{C}, \mathrm{pH} 7.4$ ) and then processed by the method of Murakami et al. (1977). After dehydration in an increasing ethanol series, the specimens we dried by the critical point method, coated with gold in vacuum and studied by the Tesla BS 340 scanning electron microscope.

\section{Results}

The plexus chorioideus ventriculi quarti forms a lot of small glomoid structures (Plate I, Fig. 1). At greater magnification it can be seen that apical membranes of individual epithelial cells are convex, covered with low dense microvilli. Among them, there are sporadic or aggregated spherical secretory protrusions of different sizes (Plate I, Fig. 2). The presence of cilia was not recorded. Occurrence of epiplexal cells is rare. They have irregular bodies with thicker processes, which, either on their periphery or as a whole, form "ruffled membranes". The surface of cells and their processes is smooth.

The plexus chorioideus ventriculi tertii is folded to a lesser degree than that in the fourth ventricle. The convex apical membranes of epithelial cells are covered with dense, short microvilli; cilia are absent. Small spherical protrusions are only sporadic. The occurrence of epiplexal cells on this part of the plexus chorioideus surface is frequent. Their bodies are irregularly round, almost elongated with smooth surface. Some of the cells have a great number of thin, fibrous processes from which the secondary branches originate (Plate I, Fig. 3A). Other epiplexal cells have 3-5 processes which are changed to "ruffled" membranes either totally or partly (Plate I, Fig. 3B).

In the region of the foramen interventriculare (FIV), the plexus chorioideus is more folded than that in the third ventricle. The convex apical membranes of epithelial cells are covered with dense microvilli; cilia are absent in this region, too. The presence of epiplexal cells in this region is abundant (Plate II, Fig. 4A). The cellular bodies have irregular, oval to triangular shapes with smooth surfaces. At least 3 thinner processes originate from the body, which may form "ruffled" membranes in the periphery. On some sites of the region of the FIV among epithelial cells, there are round, almost irregular, pore-like gaps (with a diameter of 2-10 $\mu \mathrm{m}$ ). They are either empty or with 1-2 epiplexal cells in them (Plate II, Fig. 4B). Spherical protrusions did not occur in the region FIV.

The PCH ventriculi lateralis surface is folded in the same way as that in the third cerebral ventricle. Irregularly large convex apical membranes are covered with dense microvilli or thick, microvillus-like structures. On the various sites, there are sporadic or abundant, spherical protrusions of different sizes (Plate III, Figs. 5A, 5B). The presence of EPC is rare, even if they are present, they are only on the sites without spherical protrusions. Their outer morphology is similar to that of the EPCs occurring in the third cerebral ventricle. In this region no cilia were recorded either.

\section{Discussion}

The plexus chorioideus is generally marked by the formation of recesses with large "tufts", of different sizes, which according to Ho s oy a and Fujita (1973) resemble grapes. In adult goats, the $\mathrm{PCH}$ is the most folded in the fourth ventricle, therefore it is very fragile. The same arrangement of the PCH ventriculi quarti has already been noted in 62-day-old goat foetuses (Rajtová 1997).

The PCH surface of adult goats is enlarged due to a convex arching of the apical membranes of epithelial cells, which according to Yamadori (1972) resemble low, round hillocks. Their presence also in goats has a characteristic appearance.

The convex apical membranes of the PCH in the goats studied are covered with dense microvilli or thick, microvillus-like structures such as for example in dogs reported by 
Allen (1975), in rats by Yamadori (1972) and Chamberlain (1974). Masuzawa and Sato (1983) divided microvilli on the PCH into 1) symmetrically digitated and 2) short, round, almost club-like ones. The presence of cilia on the PCH surface in the goats studied was not recorded. Moreover, in goat foetuses (Rajtová 1997) there were short cilia arranged in clusters on the tops of the PCH apical membranes of the lateral and fourth ventricle. The presence of cilia in rats was not reported by Peters (1974) either. Their occasional presence on the $\mathrm{PCH}$ has been recorded by some authors in prenatal rather than postnatal period (Tennyson and Pappas 1968; Santolaya and Rodriguez Echandia 1968; Scott et al. 1972, 1974; Chamberlain 1973; Coates 1977; Persky 1980; Otani and Tanaka 1988; Rajtová 1997), which is in agreement with our findings.

Spherical protrusions of various sizes were a part of the PCH surface in adult goats. Their abundance was recorded in the ventriculus lateralis, sporadically in the third and fourth ventricle; they were absent in the foramen interventriculare region. Unlike adult goats, in goat foetuses the occurrence of spherical protrusions was abundant in the fourth, but sporadic in the third and lateral ventricles. The spherical protrusions on the PCH surface have been recorded by more authors (e.g. Santolay a and Rodriguez Echandia 1968; Clementi and Marini 1972; Peters 1974; Scott et al. 1974; Allen 1975; Coates 1977; Raj tová 1997) and all the authors consider them as a manifestation of the secretory activity of PCH.

The presence of epiplexal cells has been recorded on the $\mathrm{PCH}$ surface both in goat foetuses and in adult goats (Rajtová 1997). Their occurrence in the region of the fourth and lateral cerebral ventricles was only sporadic. They occurred in a greater number on the $\mathrm{PCH}$ surface of the third ventricle, while in the region of the FIV they were abundant.

The presence of epiplexal (Kolmer's) cells as well as supraependymal cells in the ventricular system of the brain in foetuses or in the postnatal period of some species of mammals has been reported by more authors (Scott et al. 1972, 1974; Kitamura 1972; Hosoya and Fujita 1974; Chamberlain 1974; Bleier et al. 1975; Allen 1975; Mestres and Breipohl 1976; Coates 1977; Ling 1983; Otani and Tanaka 1988). The outer morphology of these macrophage-like cells is polymorphous; this follows from the study of the above-mentioned authors as well as from our results and not only in sheep and goat foetuses (Rajtová 1997) but also in the adult goats studied. Clementi and Marini (1972) in the cat, Hosoya and Fujita (1973) in the rat or Allen (1975) in the dog described two types of epiplexal cells: those with fibrous processes and those with pseudopodia. These data correspond to those in adult goats where EPC with pseudopodia prevailed. The authors, dealing with EPC description, have not mentioned the manner of their distribution on the $\mathrm{PCH}$ surface; in adult goats we recorded their greatest abundance in the foramen interventriculare region, where spherical protrusions were absent. Based upon the outer morphology of these macrophage-like cells in adult goats we can suppose that EPC with fibrous processes will represent the "rest" stage, and cells with pseudopodia, which are partially or entire changed to "ruffled" membranes, the "migrating" stage (Hosoya and Fujita 1973; Allen 1975; Coates 1977).

Most of the authors, studying EPC, concur in considering them to macrophages (Kitamura 1973; Hosoya and Fujita 1973; Chamberlain 1974; Bleier et al. 1975; Sturrock 1978, 1988; Maxwell and McGadey 1988). According to Maxwell and McGadey (1988) the EPC are more active than, for example supraependymal cells, which is especially pronounced in brain impairment. Mestres and Breipohl (1976) or Sturrock (1988) consider these cells as glial cells capable of movement not only on the ependymal surface but also on the PCH. Other authors reported on their haematogenic origin (Carpenter et al. 1970; Kitamura 1973; Ling 1983; Boya et al. 1986; Maxwell and McGadey 1988). Bienzle et al. (1995) have described the haematopoietic activity in the 
$\mathrm{PCH}$ of the fourth ventricle of adult dogs possibly following the impairment of blood vessels.

We have not made a statement about the origin of the epiplexal cells we described in adult goats due to the fact that our study was performed only by the scanning electron microscope. No differences, related to sex, oestrous cycle of females, or resting period of males, were recorded in the structure of the $\mathrm{PCH}$ surface in adult individuals as had been the case with ependymal lining (Rajtová 1990).

\section{Plexus chorioideus dospelej kozy: štúdium v riadkovacom elektrónovom mikroskope}

V práci bol študovaný povrch plexus chorioideus čtvrtej, tretej a laterálnej mozgovej komory a $\mathrm{v}$ oblasti foramen interventriculare u dospelých kôz obojeho pohlavia pomocou riadkovacieho elektrónového mikroskopu. Bolo zistené, že konvexné apikálne membrány po celom povrchu plexus chorioideus pokrývajú mikroklky a mikroklkom podobné štruktúry. Prítomnosṫ cílií nebola zaznamenaná. V oblasti laterálnej mozgovej komory nachádzali sa hojné sférické protrúzie, ktoré však chýbali $\mathrm{v}$ oblasti foramen interventriculare. Epiplexové bunky sa vo štvrtej a v laterálnej komore nachádzali sporadicky, vo väčšom počte sa vyskytovali v tretej komore a v oblasti medzikomorového otvoru. Niektoré epiplexové bunky mali mnoho vláknitých výbežkov, väčšina týchto makrofágom podobných buniek mala len 3-5 pseudopódií tvoriace „zvlnené“ membrány. Neboli zaznamenané rozdiely súvisiace s pohlavnou diferenciáciou alebo ročným obdobím.

\section{References}

ALLEN, D. J. 1975: Scanning electron microscopy of epiplexus macrophages (Kolmer cells) in the dog. J. Comp. Neurol. 161: 197-214

BIENZLE, D., KWIECIEN, M., PARENT, J. 1995: Extramedullary hematopoiesis in the choroid plexus of five dogs. Vet. Pathol. 32: 437-440

BLEIER, R., ALBRECHT, R., CRUCE, J. A. F. 1975: Supraependymal cells of hypothalamic third ventricle: identification as resident phagocytes of the brain. Science 189: 299-301

BOYA, J., CALVO, A. L., GARCIA-MARINO, E. 1986: Nature of macrophages in the rat brain. Acta Anat. 127: $142-145$

CARPENTER, S. J., Mc CARTHY, L. E., BORDISON, H. L. 1970: Electron microscopic study of the epiplexus (Kolmer) cells of the cat choroid plexus. Z. Zellforsch: 110: 471-486

CHAMBERLAIN, J. G. 1973: Analysis of developing ependymal and choroidal surfaces in rat brains using scanning electron microscopy. Develop. Biol. 31: 22-30

CHAMBERLAIN, J. G. 1974: Scanning electron microscopy of epiplexus cells (macrophages) in the fetal rat brain. (1). Am. J. Anat. 139: 443-446

CLEMENTI, F., MARINI, D. 1972: The surface fine structure of the walls of cerebral ventricles and of choroid plexus in cat. Z. Zellforsch. 123: 82-95

COATES, P. W. 1977: The third ventricle of monkeys. Scanning electron microscopy of surface features in mature males and females. Cell Tissue Res. 177: 307-316

HOSOYA, Y., FUJITA, T. 1973: Scanning electron microscope observation of intraventricular macrophages (Kolmer cells) in the rat brain. Arch. Histol. Jap. 35: 133-140

KITAMURA, T. 1973: The origin of brain macrophages some considerations on the microglia theory of delHortega. Acta Path. Jap. 23: 11-26

LING, E. A. 1983: Scanning electron microscopic study of epiplexus cells in the lateral ventricles of the monkey (Macaca fascicularis). J. Anat. 137: 645-652

MAXWELL, W. L., Mc GADEY, J. 1988: Response of intraventricular macrophages after a penetrant cerebral lesion. J. Anat. 160: 145-155

MASUZAWA, T., SATO, F. 1983: The enzyme histochemistry of the choroid plexus. Brain 106: 55-99

MESTRES, P., BREIPOHL, W. 1976: Morphology and distribution of supraependymal cells in the third ventricle of the albino rat. Cell Tissue Res. 168: 303-314

MURAKAMI, T., YAMAMOTO, K., ITOSHIMA, T. 1977: Modified tannin-osmium conductive staining method for non-coated SEM specimens and application to microsection SEM of spleen. Arch. Histol. Jap. 40: 35-40

O-RAHILLY, R., MÜLLER, O. 1990: Ventricular system and choroid plexus of the human brain during the embryonic period proper. Am. J. Anat. 189: 289-302 
OTANI, H., TANAKA, O. 1988: Development of the choroid plexus anlage and supraependymal structures in the fourth ventricular roof plate of human embryos: Scanning electron microscopic observations. Am. J. Anat. 181: 53-66

PERSKY, B. 1980: Scanning electron microscopy of the epiplexus cells of the dog, gerbil and guinea-pig. Anat. Rec. 190: 508 (Abstr.)

PETERS, A. 1974: The surface of the choroid plexus and ependymal lining of the rat lateral ventricle. J. Neurocytol. 3: $99-108$

PETERS, A., SWAN, R. C. 1979: The choroid plexus of the mature and aging rat: The choroidal epithelium. Anat. Rec. 194: 325-354

RAJTOVÁ, V. 1990: Ependyma of the goat. I. The third cerebral ventricle: Scanning electron microscope study. J. Hirnforsch. 31: 415-421

RAJTOVÁ, V. 1997: Chorioid plexus in sheep and goat: A scanning electron microscopy of the foetuses. Acta Vet. Brno 66: 199-202

SANTOLAYA, R. C., RODRIGUEZ ECHANDIA, E. L. 1968: The surface of the choroid plexus cell under normal and experimental conditions. Z. Zellforsch. 92: 43-51

SCOTT, D. E., PAULL, W. K., KROBISCH DUDLEY, G. 1972: A comparative scanning electron microscopic analysis of the human cerebral ventricular system. Z. Zellforsch. 132: 203-215

SCOTT, D. E., Van DYKE, D. H., PAULL, W. K., KOZLOWSKI, G. P. 1974: Ultrastructural analysis of the human cerebral ventricular system. III. The choroid plexus. Cell Tissue Res. 150: 389-397

STURROCK, R. R. 1978: A developmental study of epiplexus cells and supraependymal cells and their possible relationship to microglia. Neuropathol. Appl. Neurobiol. 4: 307-322

STURROCK, R. R. 1988: The beta astrocyte: Its possible role as a central nervous system phagocyte. Anat. Anz. 166: $331-340$

TENNYSON, V. M., PAPPAS, G. 1968: The fine structure of the choroid plexus: Adult and development stages. Progr. Brain Res. 29: 63-85

YAMADORI, T. 1972: A scanning electron microscopic observation of the choroid plexus in rats. Arch. Histol. Jap. 35: 89-97 
Plate I

Rajtová V.: The Plexus... pp. 167-171

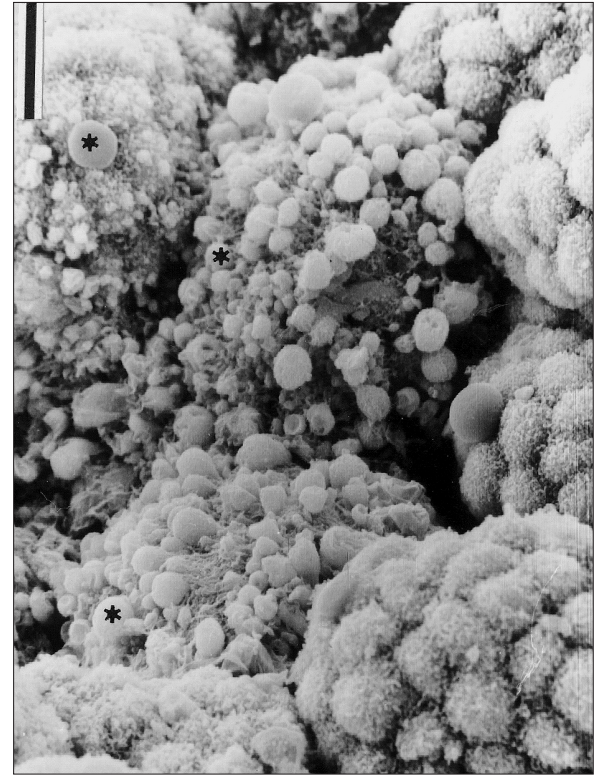
of the fourth cerebral ventricle with abundant, secretory protrusions of different sizes. $\mathrm{Bar}=20 \mu \mathrm{m}$.

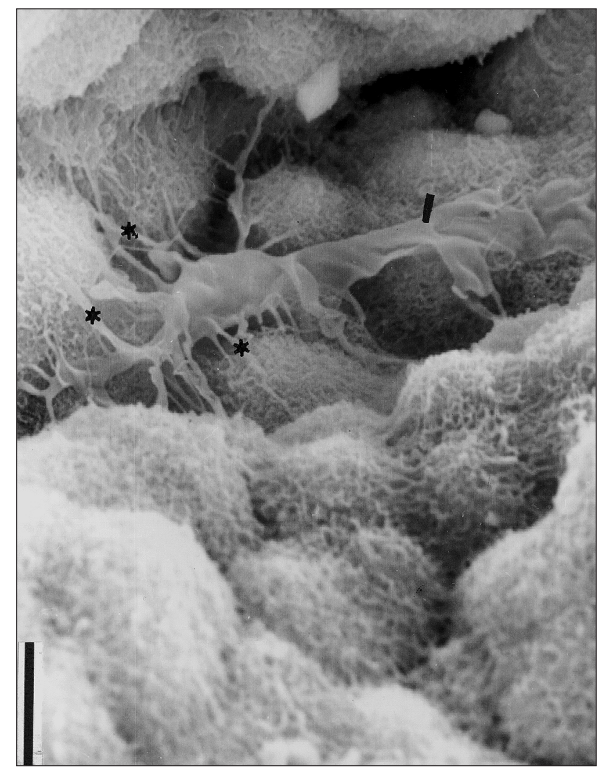

Fig. 1. The plexus chorioideus surface from the region

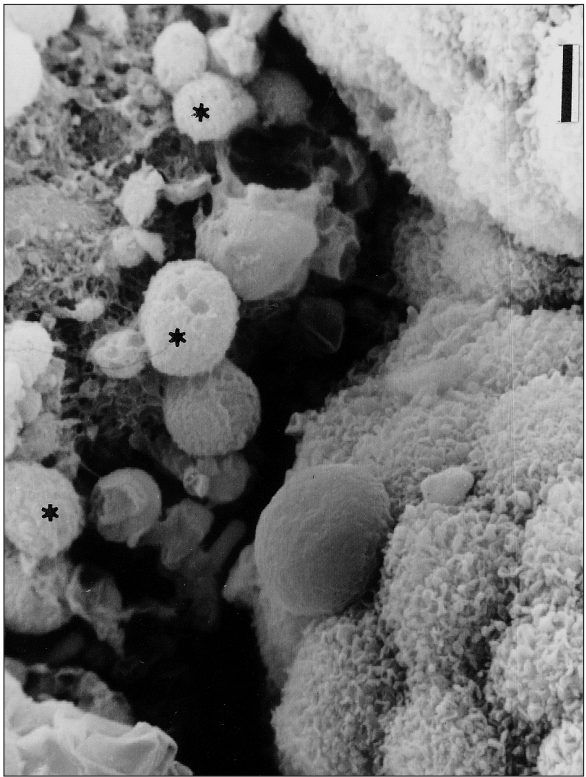

Fig. 2. The plexus chorioideus ventriculi quarti surface. The convex apical membranes are covered with dense, microvillus-like structures. Secretory protrusions protrude through the slit between recesses. Bar $=5 \mu \mathrm{m}$.

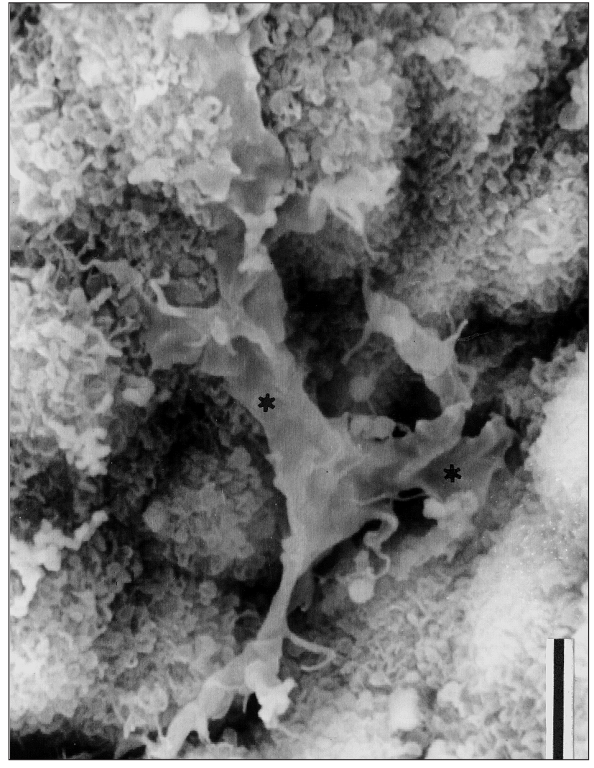

Fig 3. A B Details of the plexus chorioideus ventriculi tertii surface with epiplexal cells. A: EPC with many filiform processes. One of them is changed to "ruffled" membrane (arrow), B: EPC with pseudopodia which are entirely or partially changed to "ruffled" membranes. The surface of convex apical membranes is covered with thick, microvillus-like structures $\mathrm{A}$ : Bar $=5$. $\mu \mathrm{m}, \mathrm{B}: \mathrm{Bar}=5 \mu \mathrm{m}$ 
Plate II
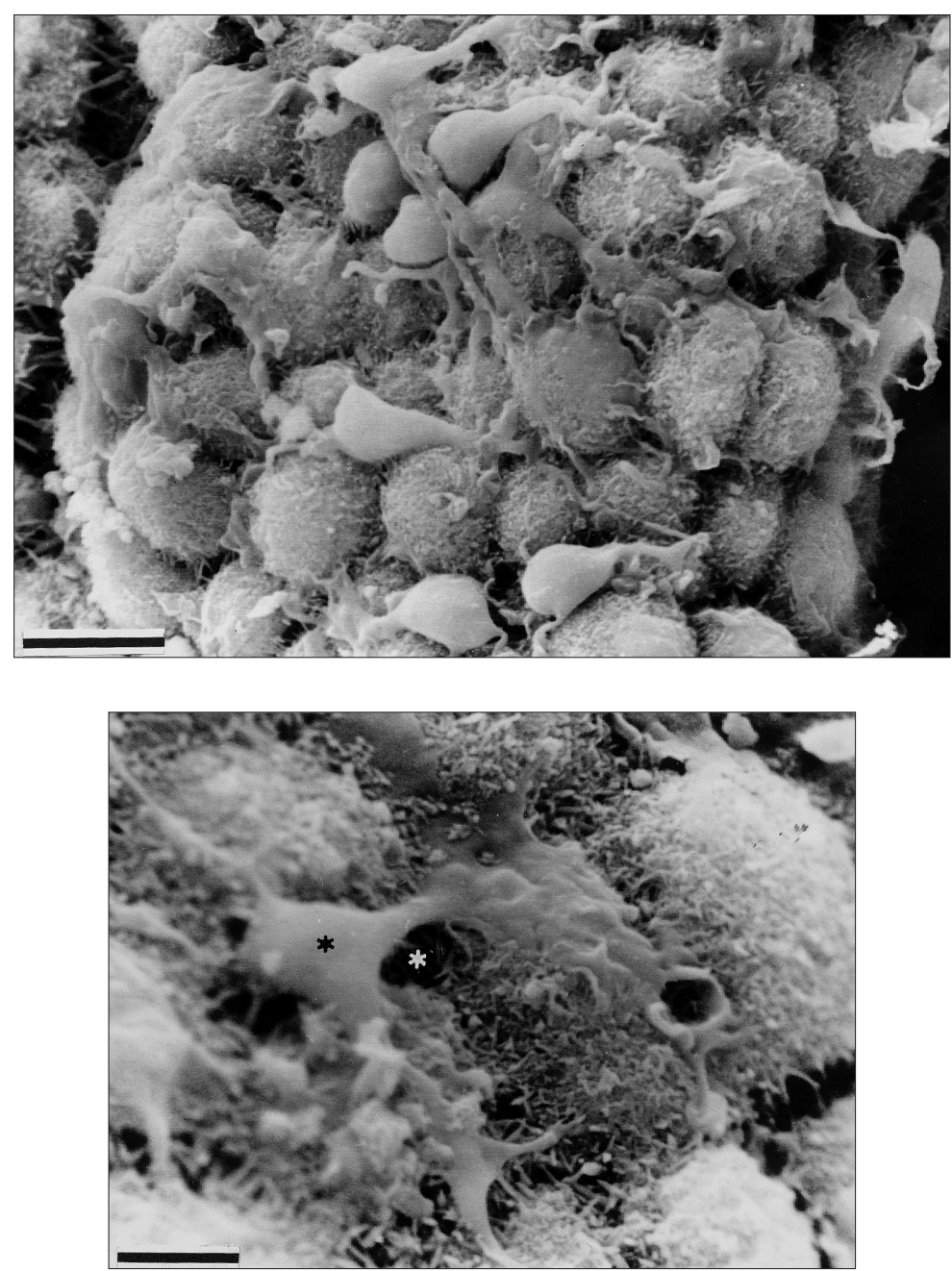

Fig. 4. A, B. The plexus chorioideus surface from the foramen interventriculare region. The convex apical membranes are covered with dense microvilli. A: EPC with pseudopodia are abundant, they get to the surface through intercellular spaces. Bar $=10 \mu \mathrm{m}$. B: Detail from the same region. One of the intercellular spaces covers $\mathrm{EPC}$, the other is loose. $\mathrm{Bar}=5 \mu \mathrm{m}$. 
Plate III
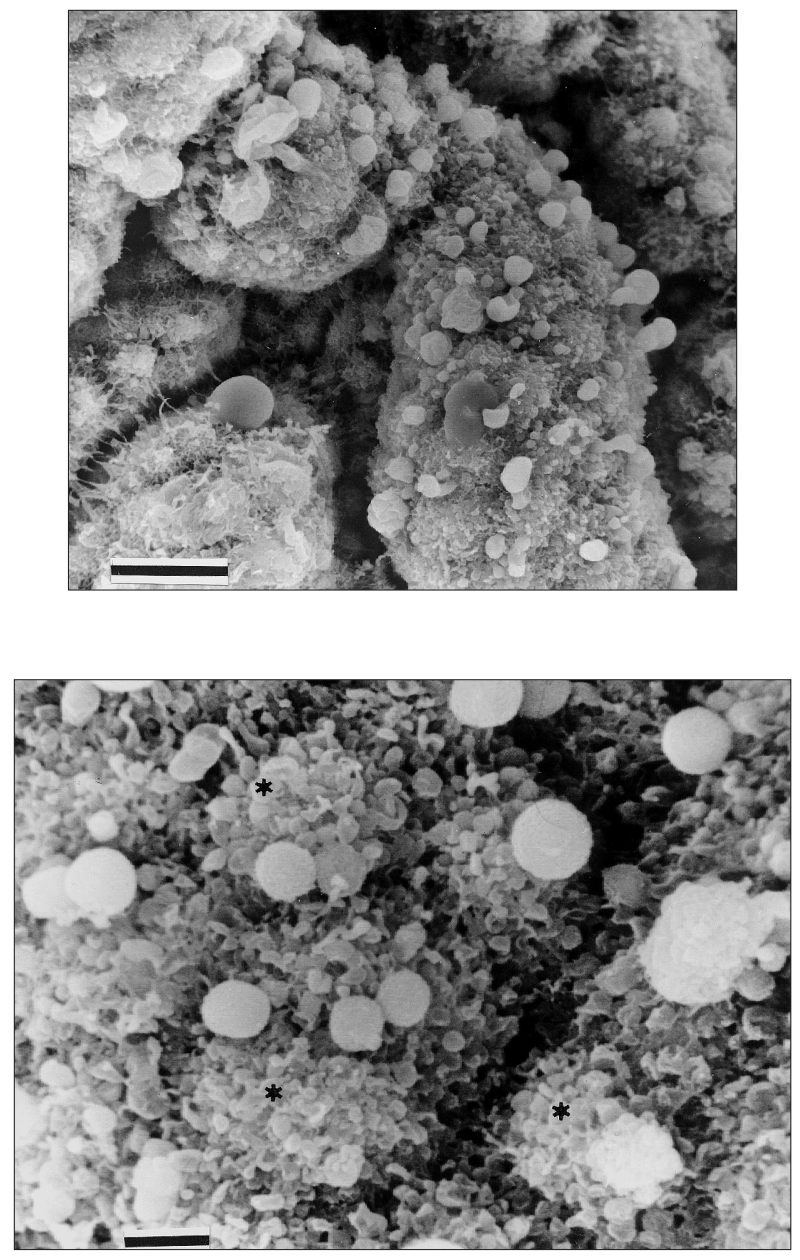

Fig. 5. A, B. The plexus chorioideus ventriculi lateralis surface is covered with microvilli and microvillus-like thick structures. Secretory protrusions are abundant. A: Bar $=20 \mu \mathrm{m}, \mathrm{B}: \mathrm{Bar}=5 \mu \mathrm{m}$. 